\title{
Evaluation of endocrine disruption and dioxin-like effects of organic extracts from sewage sludge in autumn in Beijing, China
}

\author{
Cao LIU ${ }^{1,2}$, Yiping XU ${ }^{1}$, Mei MA ${ }^{1}$, Bingbin HUANG ${ }^{2}$, Jingdong $\mathbf{W U}^{2}$, Qingyi MENG ${ }^{2}$, Zijian WANG (凶) ${ }^{1}$, \\ Robert Alan GEARHEART ${ }^{3}$ \\ 1 State Key Laboratory of Environmental Aquatic Chemistry, Research Center for Eco-Environmental Sciences, Chinese Academy of Sciences, \\ Beijing 100085, China \\ 2 Beijing Water Science and Technology Institute, Beijing 100048, China \\ 3 Environmental Engineering Department, Humboldt State University, Arcata, CA95521, USA
}

(C) Higher Education Press and Springer-Verlag Berlin Heidelberg 2013

\begin{abstract}
Study on effective disposal and utilization of sewage sludge has recently been the target of growing interest in China. However, potential risks are associated with the use of sludge due to its contamination with toxic organics, heavy metals and pathogenic microorganisms. In this study, a screening assessment was conducted on sewage sludge samples collected from 17 different sewage treatment plants in Beijing, based on a batch of in vitro bioassays, including a set of recombinant gene yeast assays for endocrine disruption, and an ethoxy resorufin-Odeethylase (EROD) assay using H4IIE cells for aryl hydrocarbon receptor (Ah-R) agonistic activities. Our results suggested that moderate levels of estrogen receptor agonistic activities $\left(0.9 \mathrm{ng} \mathrm{E} 2 \cdot \mathrm{g}^{-1}\right.$ to $\left.6.8 \mathrm{ng} \mathrm{E} 2 \cdot \mathrm{g}^{-1}, \mathrm{dw}\right)$, but relative higher androgen receptor antagonistic activities (nd to 45\%), progestin receptor antagonistic activities (nd to 80\%) and Ah-R agonistic activities (1390 to $6740 \mathrm{pg}$ 2,3,7,8-tetrachlorodibenzo-p-dioxin (TCDD) $\cdot \mathrm{g}^{-1}, \mathrm{dw}$ ) were found in sewage sludge samples. However, there were no significant correlations between the toxic effects of sewage sludge and the sewage treatment processes. In addition, the $17 \beta$-estradiol (E2) equivalent quantity (EEQ) level of the sewage sludge was increased after the composting treatment, whereas the 2,3,7,8-tetrachlorodibenzo- $p$-dioxin toxic equivalent quantity (TEQ) level of sewage sludge composted was much lower than that of sewage sludge.
\end{abstract}

Keywords sewage sludge, in vitro bioassay, endocrine disruption, dioxin-like effect

Received November 15, 2011; accepted May 8, 2013

E-mail: wangzj@rcees.ac.cn

\section{Introduction}

With the increasing numbers of sewage treatment plants (STPs) and the improvement of treatment rate and degree, the amount of sewage sludge has sharply grown in Beijing in recent years. In 2008, the output of sewage sludge was 1.035 million tons, with $80 \%$ rate of water content. It was estimated that the amazing output of sewage sludge would be about 2 million tons in 2015, with $80 \%$ water holding capacity [1].

The major pollutants of sewage water treatment were organic pollutants, high ammonia nitrogen, odor substances and biologic hormones besides sediments, colloids and casual organisms. These pollutants played roles as "micro-pollutants" in activated sludge due to their low concentrations. However, the public health would be threatened when several micro-pollutants with severe toxicity and harmness were released to the environment from sewage sludge. Especially, endocrine-disrupting chemicals (EDCs) are a newly defined category of environmental contaminant that interferes with the function of endocrine system [2]. An increasing body of evidence reveals associations between various therapeutic/ environmental compounds that act as EDCs and many sex hormone-sensitive disease/disorder [3]. These chemicals mimic the structure of the natural hormones found in the animal/human body. They enter the body of animals/ humans through the diet or occupational exposure and thus bind to the respective endogenous receptors. This leads to the generation of an agonistic or antagonistic effect even when the endogenous hormone is absent. Due to this unwanted effect, there is a change in the hormonal 
orchestra of the body that leads to the production of a number of diseases like various types of cancer, cryptorchidism, decrease in the sperm count and male reproductive capacity, as well as various types of skin diseases $[3,4]$. Majority of the effects observed in the aquatic environment concerning the reproductive system, for instance, the feminization of male fish with sewage treatment plant effluents, are attributed to the presence of EDCs [5]. The individual compounds that are responsible for these harmful effects are currently unknown, whereas many substances like nonylphenols, phthalic esters, PCBs, dioxins, polycyclic aromatic hydrocarbons (PAHs), phytoestrogens, estrogens, androgens, and progesterone are suspected to influence the hormonal systems and they are abundant in different water bodies [6]. It has been hypothesized that the statistically derived decrease in sperm counts over the last decades, increasing incidents of testicular cancer and other disorders regarding male infertility may be caused by the intake of these chemicals via food or drinking water $[7,8]$.

To ensure a hazard-free treatment and reclamation of sewage sludge, it is urgent and important to investigate the removal effectiveness of those pollutants by the current processes in STPs and further development for their removals. Although chemistry analysis can detect increasing numbers of pollutants via the modern powerful analytical chemical techniques, such as the chromatography coupled with mass spectrometry or nuclear magnetic resonance, the given fact is that instrumental analyses are expensive, and only a few of the organic pollutants can be identified in several cases [9]. Fortunately, several other alternatives demonstrated their potential applications in this area. For example in vitro bioassay has the advantages of fast detection speed, low cost, high sensitivity, and large flux. These methods enable estimation of total biologic activity of all compounds that act through the same mode of action present in extracts of any environmental media and it also integrate possible interactions among chemicals [10]. It was rapidly applied for early warning in risk assessment and specificity indicating of pollutants. Besides, some researchers had employed bioassay screening test to identify $\mathrm{Ah}$ receptor agonists in sediment and soil successfully $[11,12]$.

In this study, we focused on the screening toxic bioassays of sewage sludge samples from 17 typical STPs in Beijing. All the sludge samples were collected from the outputs of the sewage sludge dewater rooms, which include the primary settling sludge and the second sedimentation sludge. We chosed the non-flooding season for sampling in order to obtain more pollutants. The objective is to examine the levels of endocrine disruptor and dioxin-like chemicals in the sewage sludge. Our results would be very helpful for qualitative health risk assessment and further chemical evaluation.

\section{Materials and methods}

\subsection{Samples collection}

Sewage sludge samples were collected from STPs located in urban and suburban in Beijing (Fig. 1). Five sampling sites were located in typical urban STPs, i.e., Qinghe, Jiuxianqiao, Wujiacun, Fangzhuang and Lugouqiao, respectively. The others were located separately in the suburban districts of Beijing. Four kilograms of sewage sludge samples were collected in each site. All the sewage sludge samples were then stored at $-20^{\circ} \mathrm{C}$ until further treatment and analysis.

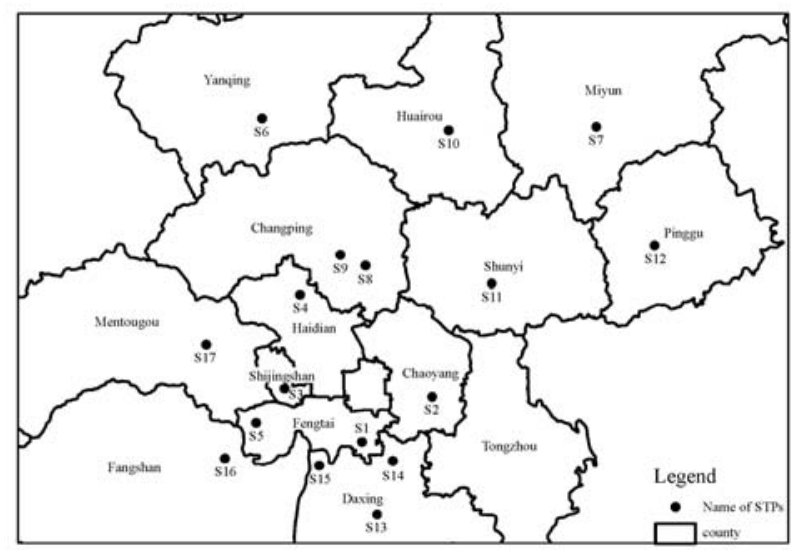

Fig. 1 Locations of sewage sludge sampling sites in Beijing. S1- Fangzhuang, S2- Jiuxianqiao, S3- Wujiacun, S4- Qinghe, S5Lugouqiao, S6- Yanqing, S7- Miyun, S8- Changping, S9Changping composted, S10- Huairou, S11- Shunyi, S12- Pinggu, S13- Huangcun, S14- Panggezhuang, S15- Yizhuang, S16Liangxiang, S17- Mentougou

\subsection{Samples pretreatment}

Sludge samples were freeze-dried and followed by Soxhlet extraction using dichloromethane/acetone $(1: 1, \mathrm{v} / \mathrm{v})$ for 24 $\mathrm{h}$. Then the extracts were passed through glass column filled with anhydrous $\mathrm{Na}_{2} \mathrm{SO}_{4}$ to remove water. The extracts were then concentrated by rotary vacuum evaporation followed by blowing a stream of high purity nitrogen to complete dryness. The residues were weighted and dissolved in dimethyl sulfoxide (DMSO, ACS grade, Sigma Chemical Co.,USA) to the required concentrations for the test. The procedure is adapted from that used for sediment samples as documented in the literature [11].

\subsection{Yeast bioassay}

The yeast strains specifically transformed with the estrogen receptor (ER), androgen receptor (AR) and progestin 
receptor $(\mathrm{PR})$ genes were constructed in our laboratory and grown on synthetic dextrose(SD) medium (lacking tryptophan and leucine, SD/-Trp/-Leu) according to description of Li et al. [13]. Another yeast strain transformed with the PR gene was a kind gift of Dr. Kevin W. Gaido (Chemical Industry Institute of Toxicology, Research Triangle Park, North Carolina, USA), which was grown in synthetic complete (SC) medium with tryptophane, but lacking histidine and leucine (SC/-His/-Leu) following the prescription of Gaido et al. [14].

The yeast assay was conducted as described by Ma et al. [15]. In performing the assay, cultures in the exponential growth phase (grown overnight) were diluted with $\mathrm{SD} /$ Leu/-Trp or SC/-His/-Leu medium to an $\mathrm{OD}_{600 \mathrm{~nm}}$ of 0.75 . All assays were conducted in at least triplicate. Each triplicate included a positive control and a negative control (DMSO). $5 \mu \mathrm{L}$ of serial dilutions of test samples were combined with $995 \mu \mathrm{L}$ of medium containing $5 \times 10^{3}$ yeast cells $\cdot \mathrm{mL}^{-1}$ resulting in a test culture in which the volume of DMSO did not exceed $1.0 \%$ of the total volume. $200 \mu \mathrm{L}$ of the test cultures were transferred into each well of the 96-well plate and incubated at $30^{\circ} \mathrm{C}$ with vigorous orbital shaking $\left(800 \mathrm{r} \cdot \mathrm{min}^{-1}\right)$ on a titer plate shaker (Heidolph TITRAMAX 1000, Hamburg, Germany) for 2 $\mathrm{h}$. The cell density of the culture was measured at $600-\mathrm{nm}$ wavelength (TECAN GENios A-5002, Salzburg, Austria).

A $50 \mu \mathrm{L}$ test culture was transferred to a new 96-well plate. After addition of $120 \mu \mathrm{L}$ of Z-buffer $\left(16.1 \mathrm{~g} \cdot \mathrm{L}^{-1}\right.$ $\mathrm{Na}_{2} \mathrm{HPO}_{4} \cdot 7 \mathrm{H}_{2} \mathrm{O} ; 5.5 \mathrm{~g} \cdot \mathrm{L}^{-1} \quad \mathrm{NaH}_{2} \mathrm{PO}_{4} \cdot \mathrm{H}_{2} \mathrm{O} ; 0.75 \mathrm{~g} \cdot \mathrm{L}^{-1}$ $\left.\mathrm{KCl} ; 0.246 \mathrm{~g} \cdot \mathrm{L}^{-1} \mathrm{MgSO}_{4} \cdot 7 \mathrm{H}_{2} \mathrm{O}\right)$ and $20 \mu \mathrm{L}$ chloroform, the culture was carefully mixed (vortex $25 \mathrm{~s}$ ) and preincubated for $5 \mathrm{~min}$ at $30^{\circ} \mathrm{C}$. The enzyme reaction was initiated by addition of $40 \mu \mathrm{L} o$-nitrophenyl- $\beta$-Dgalactopyranoside $\left(13.3 \mathrm{mmol} \cdot \mathrm{L}^{-1}\right.$, dissolved in Z-buffer). The assays were incubated at $30^{\circ} \mathrm{C}$ on a titer plate shaker. The reactions were terminated by the addition of $100 \mu \mathrm{L}$ $\mathrm{Na}_{2} \mathrm{CO}_{3}\left(1 \mathrm{~mol} \cdot \mathrm{L}^{-1}\right)$. For the samples, the incubated time lasted for $60 \mathrm{~min}$. After centrifugation at $12000 \mathrm{~g}$ for 15 min (Sigma Laborzentrifugen 2K15, Osterode, Germany), $200 \mu \mathrm{L}$ of the supernatant was transferred into a new 96well plate and the $\mathrm{OD}_{420 \mathrm{~nm}}$ was determined. The $\beta$ galactosidase activity was calculated according to the following equations: $u=C_{\mathrm{s}} / t \times V \times \mathrm{D} \times O D_{\mathrm{s}}$ and $C_{\mathrm{s}}=$ $10^{-6} \times\left(A_{\mathrm{s}}\right)-A_{\mathrm{B}} / \varepsilon \times d$, where $u$ : $\beta$-galactosidase activity,
$C_{\mathrm{s}}$ is concentration of $o$-nitrophenol in the enzyme assay reaction mix, $t$ : incubation duration of the enzyme reaction, $V$ : volume of the test culture, $D$ : dilution factor, $O D_{\mathrm{s}}$ : $O D_{600}$ of test culture, $A_{\mathrm{s}}: O D_{420}$ of the enzyme reaction supernatant of the sample, $A_{\mathrm{B}}: O D_{420}$ of the enzyme reaction supernatant of the blank, $\varepsilon: \varepsilon$ for $o$-nitrophenol in the enzyme assay reaction mix, and $d$ : diameter of the cuvette $[14,16]$.

$\beta$-Galactosidase activities of the liquid yeast cultures are expressed as the means and standard deviations of the results from three independent transformed yeast clones. All samples were evaluated in triplicate for each clone. The antagonistic activity of the sample was tested by coincubation of yeast strain with nature ligand which produced a sub-maximal stimulatory response (Table 1). The method using ligands at the concentrations that would induce sub-maximal activity in combination with tested chemicals has been widely used to screen the antagonistic activity of ER, AR and PR [17]. The details were shown as Table 1.

To ensure that increased/reduced activities in the bioassay were caused by true agonistic/ antagonistic responses instead of cytotoxicity, viability was measured in cells exposed to samples at the maximum assay concentration. Yeast cells were plated as in the original assay, and then exposed for $2 \mathrm{~h}$ to exposure medium (cellspecific medium containing samples). The cell viability was determined pectrophotometrically as a change of cell density $\left(\mathrm{OD}_{600 \mathrm{~nm}}\right)$ in the assay medium. In all the bioassays, the procedural blank was also run alongside the samples to monitor for a false-positive result.

\subsection{H4IIE-EROD assay}

The EROD assay was performed according to the method described by Qiao et al. [11] and Donato et al. [18]. H4IIE rat hepatoma cells were grown in Dulbecco's minimum essential medium (Hyclone, Thermo Scientific, USA) supplemented with $10 \%$ fetal bovine serum. The cells were incubated at $37^{\circ} \mathrm{C}$, in a humidified $5 \% \mathrm{CO}_{2}$ incubator (SANYO Electric Co., Japan). For the EROD assay, cells were seeded at a density of $2 \times 10^{4}$ cell $^{\prime}$ well $^{-1}$ in a $96-$ well plate. The cells were exposed for $72 \mathrm{~h}$ to medium containing different doses of 2,3,7,8-tetrachlorodibenzo-

Table 1 In vitro bioassays for endocrine disrupting activities of sewage sludge samples

\begin{tabular}{lccc}
\hline pathway of endocrine disruption & in vitro bioassay & $\begin{array}{c}\text { reference } \\
\text { material }\end{array}$ & endpoint \\
\hline estrogen disruption & recombinant ER gene two-hybrid yeast & $17 \beta$-estradiol & ER agonistic activity \\
androgen disruption & recombinant AR gene two-hybrid yeast & dihydrotestoster-one & AR agonistic activity \\
& & flutamide & AR antagonistic activity \\
$\begin{array}{l}\text { progestin-based endocrine disrup- } \\
\text { tion }\end{array}$ & recombinant PR gene yeast & progesterone & PR agonistic activity \\
\hline
\end{tabular}

Notes: ER, estrogen receptor; AR, androgen receptor; PR, progestin receptor 
p-dioxin (TCDD) standard solutions $\left(0-140 \mathrm{pg} \cdot \mathrm{mL}^{-1}\right.$, Cambridge Isotope Laboratories, Inc., USA), dimethyl sulphoxide (DMSO solvent control, Sigma, USA), or the test samples. Thereafter, the medium was removed and $100 \mu \mathrm{L}$ of fresh medium containing $8 \mathrm{mmol} \cdot \mathrm{L}^{-1} 7$ ethoxyresorufin (Sigma, USA) and $10 \mathrm{mmol} \cdot \mathrm{L}^{-1}$ dicumarol (Sigma, USA) was added for an additional $60 \mathrm{~min}$ of incubation at $37^{\circ} \mathrm{C}$. Next, the medium was transferred to a new 96-well plate and mixed with $130 \mu \mathrm{L}$ of absolute ethanol. Resorufin-associated fluorescence was measured with the excitation/emission wavelength of $535 / 595 \mathrm{~nm}$ (TECAN GENios A-5002, Salzburg, Austria). Thereafter, the total protein content was measured as described by Bradford [19]. Data obtained from EROD assays were normalized to total cellular protein. The biologic TCDD equivalent values were calculated according to Hanberg et al. [20].comparing the inducting of enzyme activity by environmental sample extracts with the series concentration of TCDD standard. The dose-response curves for the induction of EROD activity were constructed by software ALLFIT [21]. The aryl hydrocarbon (Ah-R) agonistic activities, regarded as dioxin-like potentials, detected in the samples were standardized against 2,3,7,8-TCDD and expressed as TCDD equivalents (TEQ) in $\mathrm{pg} \mathrm{TCDD} \cdot \mathrm{g}^{-1}$ [11].

\subsection{Data analysis}

To quantify the effects of samples, the toxicity equivalent approach was used. The concentrations of estrogen receptor (ER) agonists were calculated as $17 \beta$-estradiol equivalent (EEQ), in the same way as described before [22]. Shortly, the extract was diluted gradually and the dose-response curve of the extract was obtained together with a calibration curve of E2 in the same plat. EEQ of the sample was calculated using the linear part of the doseresponse curve of the sample. Other equivalents for AR and PR agonists were calculated in the similar way regarding to their correspondent normal ligands (Table 2). The results on the antagonistic effects were simply expressed as percentage inhibition, when the samples were simultaneously incubated in the presence of corresponding normal ligands at concentrations that could stimulate the maximum agonistic effects.

\section{Results}

\subsection{Endocrine disruption}

The ER, AR and PR agonistic activities of sewage sludge samples are shown in Fig. 2 and Table 2, respectively. The concentrations of EEQ ranged from $0.9 \mathrm{ng} \mathrm{E} 2 \cdot \mathrm{g}^{-1}$ to $6.8 \mathrm{ng}$ $\mathrm{E} 2 \cdot \mathrm{g}^{-1}(\mathrm{dw})$. None of the 17 sewage sludge samples showed AR agonistic activities, whereas 14 of them showed antagonistic activities (Table 2). It was found that the androgen antagonistic activities of the sewage sludge samples ranged up to $45 \%$ inhibition in presence of DHT (Dihydrotestoster, reference chemical for AR-yeast assay). None of the sewage sludge samples showed PR agonistic

Table 2 AR and PR activities of sewage sludge in Beijing (exposure dose: $0.5 \mathrm{mg} \cdot \mathrm{well}^{-1}$ )

\begin{tabular}{|c|c|c|c|c|}
\hline \multirow{2}{*}{$\begin{array}{l}\text { sewage sludge } \\
\text { sample }\end{array}$} & \multicolumn{2}{|c|}{ agonistic activity } & \multicolumn{2}{|c|}{ rate of antagonistic activity suppression } \\
\hline & $\mathrm{AR}$ & PR & $\mathrm{AR}$ & PR \\
\hline Fangzhuang & $<\mathrm{dl}$ & $<\mathrm{dl}$ & $26 \% \pm 8 \%$ & $58 \% \pm 7 \%$ \\
\hline Jiuxianqiao & $<\mathrm{dl}$ & $<\mathrm{dl}$ & $32 \% \pm 6 \%$ & $79 \% \pm 4 \%$ \\
\hline Wujiacun & $<\mathrm{dl}$ & $<\mathrm{dl}$ & $31 \% \pm 6 \%$ & $73 \% \pm 7 \%$ \\
\hline Qinghe & $<\mathrm{dl}$ & $<\mathrm{dl}$ & $<\mathrm{dl}$ & $43 \% \pm 8 \%$ \\
\hline Lugouqiao & $<\mathrm{dl}$ & $<\mathrm{dl}$ & $45 \% \pm 3 \%$ & $80 \% \pm 7 \%$ \\
\hline Yanqing & $<\mathrm{dl}$ & $<\mathrm{dl}$ & $29 \% \pm 1 \%$ & $<\mathrm{dl}$ \\
\hline Miyun & $<\mathrm{dl}$ & $<\mathrm{dl}$ & $18 \% \pm 2 \%$ & $61 \% \pm 4 \%$ \\
\hline Changping & $<\mathrm{dl}$ & $<\mathrm{dl}$ & $34 \% \pm 4 \%$ & $67 \% \pm 3 \%$ \\
\hline Changping Composted & $<\mathrm{dl}$ & $<\mathrm{dl}$ & $<\mathrm{dl}$ & $<\mathrm{dl}$ \\
\hline Huairou & $<\mathrm{dl}$ & $<\mathrm{dl}$ & $12 \% \pm 6 \%$ & $60 \% \pm 1 \%$ \\
\hline Shunyi & $<\mathrm{dl}$ & $<\mathrm{dl}$ & $18 \% \pm 2 \%$ & $59 \% \pm 7 \%$ \\
\hline Pinggu & $<\mathrm{dl}$ & $<\mathrm{dl}$ & $<\mathrm{dl}$ & $32 \% \pm 5 \%$ \\
\hline Huangcun & $<\mathrm{dl}$ & $<\mathrm{dl}$ & $40 \% \pm 4 \%$ & $78 \% \pm 2 \%$ \\
\hline Panggezhuang & $<\mathrm{dl}$ & $<\mathrm{dl}$ & $41 \% \pm 3 \%$ & $<\mathrm{dl}$ \\
\hline Yizhuang & $<\mathrm{dl}$ & $<\mathrm{dl}$ & $33 \% \pm 4 \%$ & $46 \% \pm 8 \%$ \\
\hline Liangxiang & $<\mathrm{dl}$ & $<\mathrm{dl}$ & $31 \% \pm 6 \%$ & $20 \% \pm 7 \%$ \\
\hline Mentougou & $<\mathrm{dl}$ & $<\mathrm{dl}$ & $28 \% \pm 7 \%$ & $46 \% \pm 11 \%$ \\
\hline
\end{tabular}

Notes: < dl: below detection limit; AR, androgen receptor; PR, progestin receptor 


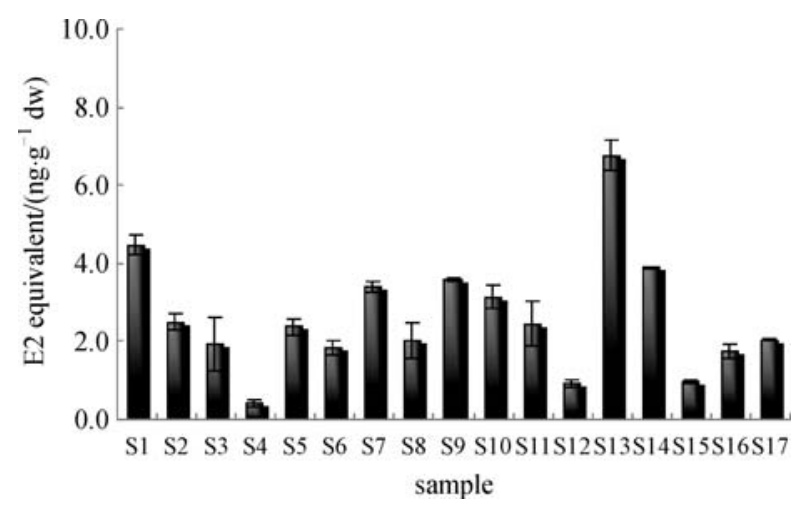

Fig. 2 Estrogen receptor agonistic activities of sewage sludge samples in Beijing (expressed as EEQ with the method detection limit of $0.9 \mathrm{ng} \mathrm{E} 2 \cdot \mathrm{g}^{-1}$ )

S1- Fangzhuang, S2- Jiuxianqiao, S3- Wujiacun, S4- Qinghe, S5Lugouqiao, S6- Yanqing, S7- Miyun, S8- Changping, S9Changping composted, S10- Huairou, S11- Shunyi, S12- Pinggu, S13- Huangcun, S14- Panggezhuang, S15- Yizhuang, S16Liangxiang, S17- Mentougou

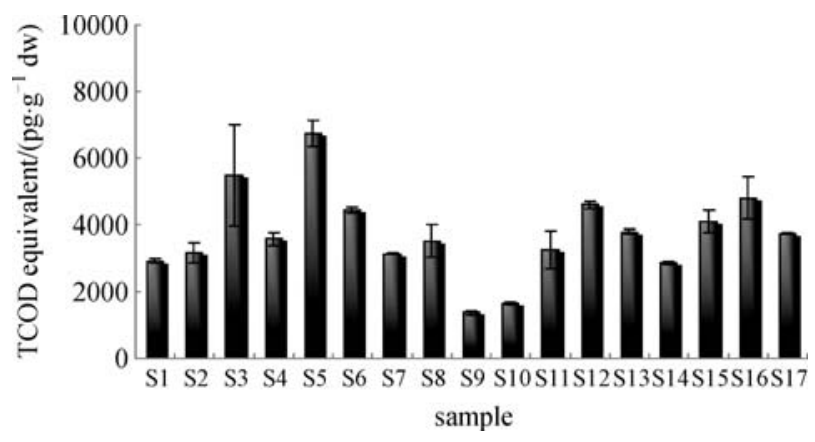

Fig. 3 Detection results of dioxin-like effects of sewage sludge samples in Beijing

S1- Fangzhuang, S2- Jiuxianqiao, S3- Wujiacun, S4- Qinghe, S5Lugouqiao, S6- Yanqing, S7- Miyun, S8- Changping, S9Changping composted, S10- Huairou, S11- Shunyi, S12- Pinggu, S13- Huangcun, S14- Panggezhuang, S15- Yizhuang, S16Liangxiang, S17- Mentougou

activities, either (Table 2). The percentage inhibition of organic extracts of sludge sample ranged up to $80 \%$ in presence of $1 \times 10^{-9} \mathrm{~mol} \cdot \mathrm{L}^{-1}$ progesterone.

\subsection{Aryl hydrocarbon receptor activity}

The Ah-R agonistic activities of sewage sludge samples in Beijing were shown in Fig. 3. The data was expressed as 2,3,7,8- TEQ in pg TCDD $\cdot \mathrm{g}^{-1} \mathrm{dw}$. TEQs of sewage sludge in Beijing ranged from 1390 to $6740 \mathrm{pg} \mathrm{TCDD} \cdot \mathrm{g}^{-1} \mathrm{dw}$. Among all the sewage sludge samples, the highest concentration of Ah-R agonists were observed at Lugouqiao (S5), whereas the lowest in Huairou (S10).

\section{Discussion}

\subsection{Estrogen receptor activity}

The estrogen receptor agonists of urban sewage sludge samples $\left(2.3 \pm 0.3 \mathrm{ng} \cdot \mathrm{g}^{-1} \mathrm{dw}\right)$ were close to those of suburban ones $\left(2.6 \pm 0.2 \mathrm{ng} \cdot \mathrm{g}^{-1} \mathrm{dw}\right)$ in Beijing. Also, there was no significant correlation $(P>0.05)$ between the detected estrogen receptor agonists and the sewage treatment processes. Comparing to the reported EEQ values of sludge, soils and sediments, the estrogen receptor agonists in Beijing sewage sludge were in the medium range (Table 3). An investigation also showed that there were high concentrations of estrogenic pollutants in the influents of five STPs and 13 types of industrial wastewater in Beijing [22]. Estrogen receptor agonists were reported as generating from natural estrogens, such as $17 \beta$-estradiol and estrone, and artificially synthesized estrogens, such as $17 \alpha$-ethynylestradiol $[23,24]$ which were often detected in the influents of the STPs.

Although S9 and S8 were taken from the same STP, after the composting process, the estrogen receptor agonists of S9 $\left(3.6 \mathrm{ng} \cdot \mathrm{g}^{-1} \mathrm{dw}\right)$ was higher than that of S8 $\left(2.0 \mathrm{ng} \cdot \mathrm{g}^{-1}\right.$ $\mathrm{dw})$. The reason was that the estrogen matters in sewage sludge, which were mainly in form of conjugated compounds (such as glucopyranosides and sulfates) [32], were activated because the conjugated bonds were unlocked during the course of composting. Therefore, the EEQ level was increased.

Table 3 Comparison of ER agonistic activities in sludge, or sediments (soils) around Beijing city [25-31]

\begin{tabular}{lc}
\hline sampling site & ER agonistic activity (EEQ)/(ng E2·g $\left.{ }^{-1}\right)$ \\
\hline sludge from STPs (The Netherlands) [25] & $<\mathrm{dl}-3.6$ \\
sludge from a STP (Germany) [26] & $0.3-3.7$ \\
sludge from STPs (Korea) [27] & $3-444$ \\
soils from reclaimed water irrigated plots (Tunisia) [28] & $<\mathrm{dl}$ \\
sediments of Wenyuhe River in Beijing (China) [29] & $0.8-19.8$ \\
sediments of Daguhe River (China) [30] & $37-95$ \\
soils in Beijing and Tianjin (China) [31] & $<\mathrm{dl}-0.14$ \\
sewage sludge in Beijing (current study) & $0.9-6.8$
\end{tabular}

Notes: ER, estrogen receptor; EEQ, 17ß-estradiol (E2) equivalent quantity; $<$ dl, below detection limit; STP, sewage treatment plant 


\subsection{Androgen receptor activity}

There were no strong differences $(P>0.05)$ observed between AR agonistic activities of sewage sludge in urban and suburb areas of Beijing. However, the AR antagonistic activities of sewage sludge varied with different STPs. There was no significant correlation $(P>0.05)$ between the androgen receptor activities and the different secondary treatment technologies. The highest level of AR antagonistic activity was detected in the sewage sludge from Lugouqiao STP (S5) and followed by Panggezhuang (S14), Huangcun (S13) and Changping (S8). No AR antagonistic activity was detected after the sludge from Changping STP was composted (S9), which indicated high remove efficiency of AR antagonistic pollutants by this kind of treatment.

Similar results were reported in the literatures that remarkable AR antagonistic activities were observed whereas few androgen agonists were detected $[13,33]$. Several studies demonstrated that a lot of polarized compounds were detected in the effluents of STPs. Some phenols, such as 4-t-octyl phenol, 2,4-dichlorophenol, bisphenol A and 4-phenyl phenol, as well as butyl benzyl phthalate, all had AR antagonistic activities. Furthermore, 4-t-octyl phenol and bisphenol A could remarkably inhibit the AR agonistic activity at low concentrations [34,35]. As a result, AR antagonistic pollutants in the sewage sludge of Beijing should be screened by further chemical analysis, such as phenols, phthalates, and some organochlorine pesticides and fungcides.

\subsection{Progestin receptor activity}

There were also no substantial differences $(P>0.05)$ observed between PR agonistic activities of sewage sludge in urban and suburb areas of Beijing, whereas the antagonistic activities of urban sewage sludge samples were stronger than those of suburban. There was no significant correlation $(P>0.05)$ between the progestin receptor activity and the different secondary treatment technologies. The sample (S5) from Lugouqiao STP had the highest level of anti-progestagenic activity, followed by Jiuxianqiao (S2), Huangcun (S13) and Wujiacun (S3).
There was no PR antagonistic activity detected after the sludge from Changping STP was composted (S9). This proved that PR antagonists were effectively removed by this kind of utilization as well.

In summary, the sewage sludge samples showed no PR agonistic activities but only antagonistic activities. Only a few PR agonists or PR antagonists have been reported in wastewater till now. Some studies proved that a few organochlorine pesticides (OCPs) and phenols, such as 4,4'-DDT, 4,4'-DDE, tetrachloro bisphenol A, tetrabromo bisphenol A and pentachlorophenol, had strong activity of PR suppression [17,36,37]. However, more studies were needed to discriminate the compounds with PR antagonistic activities in sewage sludge samples in Beijing.

\subsection{Aryl hydrocarbon receptor activity}

Ah-R agonistic activities of south-west urban sewage sludge samples were much higher than others in Beijing. However, the detected results had no significant correlation $(P>0.05)$ with the sewage treatment processes. In comparison with the Ah-R activities reported in sludge, or sediments and soils around Beijing city (Table 4), the TEQ levels (1390-6740 pg TCDD $\left.\cdot \mathrm{g}^{-1}, \mathrm{dw}\right)$ of sewage sludge in Beijing were close to those of sewage sludge in Australia (1200-15300 pg TCDD $\cdot \mathrm{g}^{-1}$, dw) and Daguhe River sediments in Tianjin (1200-13900 $\mathrm{pg}$ TCDD $\cdot \mathrm{g}^{-1}$, $\mathrm{dw})$, respectively $[28,29,38-41]$. As the Ah-R activities of Wenyuhe River sediments (10-340 pg TCDD $\left.\cdot \mathrm{g}^{-1}, \mathrm{dw}\right)$ [29], one of the urban drainages in Beijing, were much lower than those of the urban sewage sludge in Beijing, it could be supposed that dioxin-like pollutants were inclined to be accumulated in the sewage sludge and diluted by the drainage water. In conclusion, the sewage sludge in Beijing was observably contaminated by dioxins-like pollutants.

The anaerobic environment can in some cases be advantageous for dechlorination of organic pollutants, such as polychlorinated biphenyls (PCBs) and polychlorinated dibenzo- $p$-dioxins and furans (PCDDs/Fs) [42]. It was also found that the TEQ level of sewage sludge composted (S9) was much lower than that of the original sewage sludge (S8).

Table 4 Comparison of Ah-R agonistic activities in sludge, or sediments (soils) around Beijing city [28,29,38-41]

\begin{tabular}{lc}
\hline sampling sites & ${\text { Ah-R agonistic activity (TEQ, } \mathrm{pg} \mathrm{TCDD}^{-1}{ }^{-1} \text { ) }}^{\text {sewage sludge (UK) [38] }}$ \\
sewage sludge (Australia) [39] & $20-220$ \\
sewage sludge in Catalonia (Spain) [40] & $1200-15300$ \\
soils from reclaimed water irrigated plots (Tunisia) [28] & $26600-67900$ \\
sediments of Wenyuhe River in Beijing (China) [29] & $10-340$ \\
sediments of Daguhe River (China) [41] & $1200-13900$ \\
sewage sludge in Beijing (current study) & $1390-6740$ \\
\hline
\end{tabular}

Notes: Ah-R, aryl hydrocarbon receptor; TEQ, 2,3,7,8-tetrachlorodibenzo-p-dioxin (TCDD) toxic equivalent quantity 


\section{Conclusions}

In this study, the estrogen receptor agonistic activity were in moderate level whereas other sex hormone receptor agonistic activity were unremarkable in organic extracts of sewage sludge sampling from 17 STPs in Beijing, China. Meanwhile, strong activities of both androgen receptor antagonists and progestin receptor antagonists have been found in the sewage sludge. It has been also found that the sewage sludge in Beijing was evidently contaminated by dioxins-like pollutants (aryl hydrocarbon receptor activity). The detected aryl hydrocarbon receptor activities could be significantly removed by the sewage sludge composting treatment. Our results demonstrated that the estrogen agonistic activity of the sewage sludge was increased after the composting treatment.

Acknowledgements This research was funded jointly by Beijing Municipal Science \& Technology Commission (Z09040900930903), Chinese Academy of Sciences (KZCX1-YW-06-02) and Ministry of Environmental Protection of China (200809087).

\section{References}

1. Wu J D, Xiong J X, Huang B B, Li W Z, Meng Q Y, He C L. Status and countermeasures of the sludge treatment and disposal in Beijing Municipal Sewage Treatment Plants. Beijing Water, 2010, (5): 4-6 (in Chinese)

2. Cargouët M, Perdiz D, Mouatassim-Souali A, Tamisier-Karolak S, Levi Y. Assessment of river contamination by estrogenic compounds in Paris area (France). The Science of the Total Environment, 2004, 324(1-3): 55-66

3. Chen J, Ahn K C, Gee N A, Gee S J, Hammock B D, Lasley B L. Antiandrogenic properties of parabens and other phenolic containing small molecules in personal care products. Toxicology and Applied Pharmacology, 2007, 221(3): 278-284

4. Roy P, Pereira B M. A treatise on hazards of endocrine disruptors and tool to evaluate them. Indian Journal of Experimental Biology, 2005, 43(11): 975-992

5. Sumpter J P, Jobling S. Vitellogenesis as a biomarker for estrogenic contamination of the aquatic environment. Environmental Health Perspectives, 1995, 103(Suppl 7): 173-178

6. Leusch F D L, van den Heuvel M R, Chapman H F, Gooneratne S R, Eriksson A M E, Tremblay L A. Development of methods for extraction and in vitro quantification of estrogenic and androgenic activity of wastewater samples. Comparative biochemistry and physiology. Toxicology \& pharmacology, 2006, 143(1): 117-126

7. Kumar V, Chakraborty A, Viswanath G, Roy P. Androgenic endocrine disruptors in wastewater treatment plant effluents in India: their influence on reproductive processes and systemic toxicity in male rats. Toxicology and Applied Pharmacology, 2008, 226(1): 60-73

8. Sharpe R M, Skakkebaek N E. Are oestrogens involved in falling sperm counts and disorders of the male reproductive tract? Lancet, 1993, 341(8857): 1392-1396
9. Leon D Betowski, Douglas S Kendall, Christopher M Pace, Joseph R Donnelly. Characterization of groundwater samples from superfund sites by gas chromatography/mass spectrometry and liquid chromatography/mass spectrometry. Environmental Science \& Technology, 1996, 30(12): 3558-3564

10. Giesy J P, Hilscherova K, Jones P D, Kannan K, Machala M.Cell bioassays for detection of aryl hydrocarbon (AhR) and estrogen receptor (ER) mediated activity in environmental samples. Marine Pollutution Bulletin, 2002, 45(1-12): 3-16

11. Qiao M, Chen Y, Zhang Q H, Huang S B, Ma M, Wang C, Wang Z J. Identification of $\mathrm{Ah}$ receptor agonists in sediment of Meiliang Bay, Taihu Lake, China. Environmental Science \& Technology, 2006, 40(5): 1415-1419

12. Shen C F, Huang S B, Wang Z J, Qiao M, Tang X J, Yu C N, Shi D Z, Zhu Y, Shi J Y, Chen X C, Setty K, Chen Y X. Identification of Ah receptor agonists in soil of E-waste recycling sites from Taizhou area in China. Environmental Science \& Technology, 2008, 42(1): $49-55$

13. Li J, Wang Z J, Ma M, Peng X Z. Analysis of environmental endocrine disrupting activities using recombinant yeast assay in wastewater treatment plant effluents. Bulletin of Environmental Contamination and Toxicology, 2010, 84(5): 529-535

14. Gaido K W, Leonard L S, Lovell S, Gould J C, Babaï D, Portier C J, McDonnell D P. Evaluation of chemicals with endocrine modulating activity in a yeast-based steroid hormone receptor gene transcription assay. Toxicology and Applied Pharmacology, 1997, 143(1): 205-212

15. Ma M, Li J, Wang Z J. Assessing the detoxication efficiencies of wastewater treatment processes using a battery of bioassays/ biomarkers. Archives of Environmental Contamination and Toxicology, 2005, 49(4): 480-487

16. Routledge E J, Sumpter J P. Estrogenic activity of surfactants and some of their degradation products assessed using a recombinant yeast screen. Environmental Toxicology and Chemistry, 1996, 15 (3): 241-248

17. Wang J, Xie P, Kettrup A, Schramm K W. Inhibition of progesterone receptor activity in recombinant yeast by soot from fossil fuel combustion emissions and air particulate materials. The Science of the Total Environment, 2005, 349(1-3): 120-128

18. Donato M T, Gómez-Lechón M J, Castell J V. A microassay for measuring cytochrome P450IA1 and P450IIB1 activities in intact human and rat hepatocytes cultured on 96-well plates. Analytical Biochemistry, 1993, 213(1): 29-33

19. Bradford M M. A rapid and sensitive method for the quantitation of microgram quantities of protein utilizing the principle of protein-dye binding. Analytical Biochemistry, 1976, 72(1-2): 248-254

20. Hanberg A, Stahlberg M, Georgellis A, de Wit C, Ahlborg U G. Swedish dioxin survey: evaluation of the H-4-II E bioassay for screening environmental samples for dioxin-like enzyme induction. Pharmacology \& Toxicology, 1991, 69(6): 442-449

21. Pöch G, Köck P, Reiffenstein R J, Pancheva S N. Uniform characterization of potentiation in simple and complex situations when agents bind to different molecular sites. Canadian Journal of Physiology and Pharmacology, 1995, 73(11): 1574-1581

22. Ma M, Rao K F, Wang Z J. Occurrence of estrogenic effects in sewage and industrial wastewaters in Beijing, China. Environmental 
pollution (Barking, Essex: 1987), 2007, 147(2): 331-336

23. C Desbrow, E J Routledge, G C Brighty, J P Sumpter, M Waldock. Identification of estrogenic chemicals in STW effluent. 1. Chemical fractionation and in vitro biological screening. Environmental Science \& Technology, 1998, 32(11): 1549-1558

24. Viganò L, Benfenati E, Cauwenberge A, Eidem J K, Erratico C, Goksøyr A, Kloas W, Maggioni S, Mandich A, Urbatzka R. Estrogenicity profile and estrogenic compounds determined in river sediments by chemical analysis, ELISA and yeast assays. Chemosphere, 2008, 73(7): 1078-1089

25. Murk A J, Legler J, van Lipzig M M H, Meerman J H N, Belfroid A C, Spenkelink A, van der Burg B, Rijs G B J, Vethaak D. Detection of estrogenic potency in wastewater and surface water with three in vitro bioassays. Environmental toxicology and chemistry/SETAC, 2002, 21(1): 16-23

26. Körner W, Bolz U, Süßmuth W, Hiller G, Schuller W, Hanf V, Hagenmaier H. Input/output balance of estrogenic active compounds in a major municipal sewage plant in Germany. Chemosphere, 2000, 40(9-11): 1131-1142

27. Sim W J, Lee J W, Shin S K, Song K B, Oh J E. Assessment of fates of estrogens in wastewater and sludge from various types of wastewater treatment plants. Chemosphere, 2011, 82(10): 14481453

28. Mahjoub O, Leclercq M, Bachelot M, Casellas C, Escande A, Balaguer P, Bahri A, Gomez E, Fenet H. Estrogen, aryl hysdrocarbon and pregnane $\mathrm{X}$ receptors activities in reclaimed water and irrigated soils in Oued Souhil area (Nabeul, Tunisia). Desalination, 2009, 246(1-3): 425-434

29. Luo J, Ma M, Wang D, Rao K, Wang Z. Assessing potential toxicities of sediments from typical rivers in Tianjin, China by using in vitro bioassays. China Environmental Science, 2008, 28(11): 968-973

30. Song M, Xu Y, Jiang Q, Lam P K, O’Toole D K, Giesy J P, Jiang G. Measurement of estrogenic activity in sediments from Haihe and Dagu River, China. Environment International, 2006, 32(5): 676681

31. Xiao R Y, Wang Z J, Wang C X, Yu G. Soil screening for identifying ecological risk stressors using a battery of in vitro cell bioassays. Chemosphere, 2006, 64(1): 71-78

32. Dray J, Dray T F, Ullmann A. Hydrolyse des métabolites urinaires de différentes hormones stéroïdes par la-glucuronidase de "Escherichia coli”. Annales de l'Institut Pasteur, 1972, 123(6): 853-857

33. Tollefsen K E, Harman C, Smith A, Thomas K V. Estrogen receptor (ER) agonists and androgen receptor (AR) antagonists in effluents from Norwegian North Sea oil production platforms. Marine Pollutution Bulletin, 2007, 54(3): 277-283

34. Sohoni P, Sumpter J P. Several environmental oestrogens are also anti-androgens. The Journal of Endocrinology, 1998, 158(3): 327339

35. Tamura H, Ishimoto Y, Fujikawa T, Aoyama H, Yoshikawa H, Akamatsu M. Structural basis for androgen receptor agonists and antagonists: interaction of SPEED 98-listed chemicals and related compounds with the androgen receptor based on an in vitro reporter gene assay and 3D-QSAR. Bioorganic \& Medicinal Chemistry, 2006, 14(21): 7160-7174

36. Tran D Q, Klotz D M, Ladlie B L, Ide C F, McLachlan J A, Arnold S F. Inhibition of progesterone receptor activity in yeast by synthetic chemicals. Biochemical and Biophysical Research Communications, 1996, 229(2): 518-523

37. Li J, Li N, Ma M, Giesy J P, Wang Z J. In vitro profiling of the endocrine disrupting potency of organochlorine pesticides. Toxicology Letters, 2008, 183(1-3): 65-71

38. Stevens J, Green N J L, Jones K C. Survey of PCDD/Fs and nonortho PCBs in UK sewage sludges. Chemosphere, 2001, 44(6): 1455-1462

39. Clarke B, Porter N, Symons R, Blackbeard J, Ades P, Marriott P. Dioxin-like compounds in Australian sewage sludge - review and national survey. Chemosphere, 2008, 72(8): 1215-1228

40. Eljarrat E, Caixach J, Rivera J. A comparison of TEQ contributions from PCDDs, PCDFs and dioxin-like PCBs in sewage sludges from Catalonia, Spain. Chemosphere, 2003, 51(7): 595-601

41. Song M, Jiang Q, Xu Y, Liu H, Lam P K, O’Toole D K, Zhang Q, Giesy J P, Jiang G. AhR-active compounds in sediments of the Haihe and Dagu Rivers, China. Chemosphere, 2006, 63(7): 12221230

42. Engwall M, Schnürer A. Fate of Ah-receptor agonists in organic household waste during anaerobic degradation-estimation of levels using EROD induction in organ cultures of chick embryo livers. The Science of the Total Environment, 2002, 297(1-3): 105108 